\title{
POLA PEMBELAJARAN PENDIDIKAN AGAMA ISLAM DALAM PENDIDIKAN INQLUSI BAGI ANAK YANG BERKEBUTUHAN KHUSUS (ABK) DI SDIT AL AUFA KOTA BENGKULU
}

\author{
Hengki Satrisno dan Heny Friantary \\ IAIN Bengkulu \\ hengkidalima@gmail.com
}

\begin{abstract}
Education makes the needs of every human being, as an effort to maximize all the potential of the creator in order to become our human being. No exception for individuals who physically and psychologically have deficiencies and weaknesses called Children with Special Needs (ABK). To optimize the potential of these individuals, an appropriate learning pattern is needed, especially in the learning process of Islamic Religious Education. Al Aufa SDIT is an educational institution that provides Inclusive education services for ABK. Implement learning at SDIT Al Aufa using teacher and media learning patterns. Where this learning activity begins with compiling learning objectives, determining teaching material, establishing learning methods and media and evaluation instruments arranged simply. While learning activities in the classroom encountered several obstacles, namely the characteristics of $\mathrm{ABK}$ who were hyperactive, had difficulty communicating/ socializing and were slow in responding to the stimulus provided.
\end{abstract}

Keywords: Society Education, Disable, Learning Activity, SDIT Al Aufa;

\begin{abstract}
Abstrak. Pendidikan menjadikan kebutuhan setiap manusia, sebagai upaya memaksimalkan semua potensi dari sang khalik guna menjadi insan kamil. Tidak terkecuali bagi individu yang secara fisik dan psikis memiliki kekurangan dan kelemahan yang disebut dengan Anak bekebutuhan Khusus (ABK). Untuk mengoptimalkan potensi individu tersebut, maka dibutuhkan suatu pola pembelajaran yang tepat, terutama pada proses pembelajaran Pendidikan Agama Islam. SDIT Al aufa merupakan salah satu lembaga pendidikan yang memberikan layanan pendidikan Inqlusi bagi ABK. Implementasikan pembelajaran di SDIT Al Aufa menggunakan pola pembelajaran guru dan media. Dimana kegiatan pembelajaran ini diawali dengan menyusun tujuan pembelajaran, menentukan materi ajar, menetapkan metode dan media pembelajaran serta instrument evaluasi disusun secara sederhana. Sedangkan aktivitas pembelajaran di dalam kelas menemuai beberapa kendala, yaitu karaktristik ABK yang hiperaktif, susah berkomunikasi/bersosialisai dan lambat dalam merespon stimulus yang diberikan.
\end{abstract}

Kata Kunci: Pendidikan Masyarakat, ABK, Aktivitas Belajar, SDIT Al-Aufa 


\section{Pendahuluan}

Pendidikan merupakan komponen penting bagi kehidupanmanusia yang berarti setiap manusia berhak tumbuh dan berkembang dengan mendapatkan pendidikan sebagai modal dalam menjalai kehidupannya. Pendidikan secara umum mempunyai arti suatu proses kehidupan dalam mengembangkan diri setiap individu untuk dapat hidup dan melangsungkan kehidupan.Hak untuk mendapatkan pendidikan tidak hanya diperuntukan bagi anak-anak yang normal, baik secara fisik dan psikis/mental. Akan tetapi juga, bagi anak yang berkebutuhan khusus (ABK). Pendidikan bagi anak yang berkebutuhan khusus dilaksanakan di empat jenis lembaga pendidikan. Antara lain, sekolah luar biasa (SLB), Sekolah dasar Luar Biasa (SDLB) dan Sekolah Terpadu serta Sekolah Inqlusi.

SDIT Al aufa Kota Bengkulu merupakan salah satu lembaga pendidikan dasar yang menerima dan menyelenggarakan pendidikan bagi anak yang berkebutuhan khusus. Penyelenggaraan pendidikan melalui pembelajaran PAI di kelas dengan memasukan anak berkebutuhan khusus satu kelas dengan anak yang normal dengan cara memberikan perhatian dan perlakuan khusus.

Keterbatasan yang dimiliki oleh anak ABK, baik secara fisik dan psikis menjadikan desain pembelajaran, terutama dalam hal pola penyampaian/komunikasi pengajaran disesuaikan dengan kemampuan yang dimiliki anak.

\section{Pola Pembelajaran}

Pola menurut bahasa Indonesia berarti model atau system kerja dalam melakukan sesuatu. Pola pembelajaran hakikatnya merupakan proses interakasi antara guru dengan siswa, baik interakasi secara langsung maupun tidak langsung, yaitu menggunakan media pembelajaran. Ada beberapa pola pembelajaran menurut borry moris antara lain: ${ }^{1}$

a.Pola Pembelajaran Tradisional I

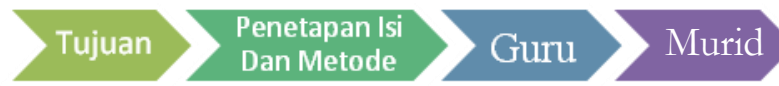

Pola pembelajaran guru dengan siswa tanpa menggunakan alat bantu atau bahan pembelajaran dalam bentuk alat peraga. Pola pembelajaran pada tipe ini bergantung kepada guru dalam mengingat materi yang diajarkan dan menyampaikan materi tersebut secara lisan kepada peserta didik.

\footnotetext{
${ }^{1}$ Borry moris dalam Rusman. Tt. Pendekatan Dan Model Pembelajaran. h.5
} 
b. Pola Pembelajaran Tradisional II

Pola pembelajaran tipe ini media yang digunakan hanya sebatas pelangkap saja, sedangkan perang guru masih yang paling dominan dalam proses belajar mengajar.

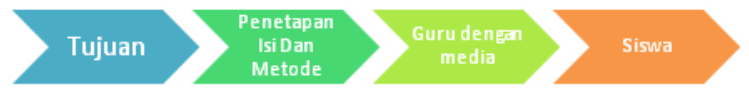

c.Pola Pembelajaran Guru Dan Media
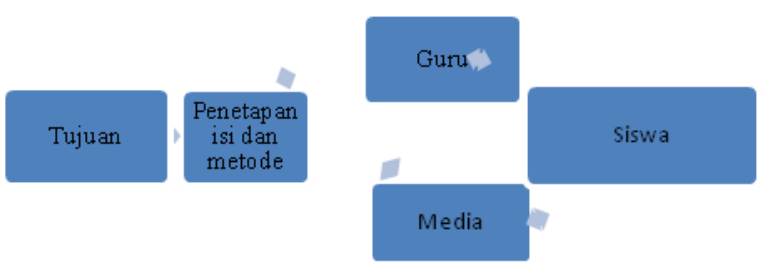

Pola pembelajaran tipe ini guru sudah memanfaatkan alat bantu atau alat peraga dalam proses pengajaran, untuk menjelaskan dan menyampaikan materi ajar kepada peserta didik

d. Pola Pembelajaran Bermedia

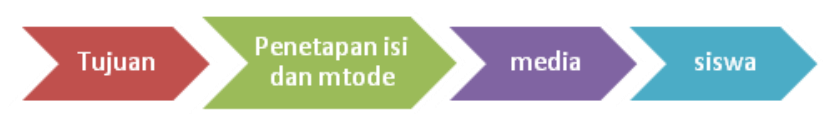

Pola pembelajaran tipe ini guru tidak lagi berperan sebagi satusatunya sumber informasi bagi siswa. Akan tetapi, siswa dapat memperoleh informasi dari berbagai media yang tersedia. Guru pada pola ini berperan sebagai pengelola belajar.

\section{Pendidikan Agama Islam}

Konsep pendidikan dalam digunakan tiga istilah, yakni. At-tarbiyyah, atta'lim dan at ta'dib. At tarbiyah menurut akar katanya berasal dari bahasa arab. Pertama, raba, yarbu artinya bertambah dan berkembang. Kedua, rabiya-yarbu yang berarti memperbaiki, ketiga rabba -yarubbu yang berarti memperbaiki, mengurusi kepentingan, mengatur, menjaga dan memperhatikan. ${ }^{2}$

Kemudian istilah pendidikan yang kedua yakni ta'lim yang cenderung di difinisikan sebagai proses penyampaian ilmu pengetahuan (transfer of knowledge).

2 Moh. Salim Haitami Salim dan Syamsul Kurniawan. Studi Ilmu Pendidikan Islam. Jogyakarta. Ar-Ruzz media. H.30 
Pengertian at'lim disini dititikberatkan sebagai suatu usaha untuk meningkatkan wawasan dan pengetahuan peserta didik.

Istilah pendidikan berikut yang sering dinakan dalam lieteratur Islam yakni ta'dib yang cenderung kepada suatu usaha untuk memberikan bimbingan dan arahan kepada peserta didik dari segi akhlak. Dari bahasa pendidikan dikenal dikenal dengan bimbingan aspek afektif. Dimana aspek yang diinginkan diarahkan kepada usaha untuk membina,membimbngan kepribadian akan menuju pribadi yang utama (paripurna).

Dari beberapa istilah pendidikan di atas term yang popular digunakan dalam praktek pendidikan Islam ialah al-tarbiyah. Sedangkan al-ta'dib dan alta'lim jarang sekali digunakan. Padahal kedua istilah tersebuttelah digunakan sejak awal pertumbuhan pendidikan Islam.Istilah al-tarbiyah berasal dari kata rabb. Walaupun kata ini memiliki banyak arti, akan tetapi pengertian dasarnya menunjukkan makna tumbuh, berkembang, memelihara, merawat, mengatur, dan menjaga kelestarian atau eksistensinya.

Pengertian pendidikan Islam yang dikandung dalam al-tarbiyah terdiri atas empat unsur pendekatan, yaitu:

1) Memelihara dan menjaga fitrah anak didik menjelang dewasa (baligh).

2) Mengembangkan seluruh potensi menuju kesempurnaan.

3) Mengarahkan seluruh fitrah menuju kesempurnaan.

4) Melaksanakan pendidikan secara bertahap.

Pada kata al-tarbiyah yang memiliki arti pengasuhan, pemeliharaan, dan kasih sayang tidak hanya digunakan untuk manusia, akan tetapi juga digunakan untuk melatih dan memelihara binatang atau makhluk Allah lainnya.

Di antara batasan yang sangat variatif tersebut adalah:

1) Mengemukakan bahwa pendidikan Islam adalah proses mengubah tingkah laku individu peserta didik pada kehidupan pribadi, masyarakat, dan alam sekitarnya.

2) Mendefinisikan pendidikan Islam sebagai upaya mengembangkan, mendorong serta mengajak peserta didik hidup lebih dinamis dengan berdasarkan nilai-nilai yang tinggi dan kehidupan yang mulia.

3) Mengemukakan bahwa pendidikan Islam adalah bimbingan atau pimpinan secara sadar oleh pendidik terhadap perkembangan jasmani dan rohani peserta didik menuju terbentuknya kepribadiannya yang utama (insan kamil).

4) Mendefinisikan pendidikan Islam sebagai bimbingan yang diberikan oleh seseorang agar ia berkembang secara maksimal sesuai dengan ajaran Islam 
Secara istilah menurut Salim, pendidikan Islam merupakan segala upaya proses pendidikan yang dilakukan untuk membimbing tingkah laku manusia, baik individ mapun sosila untuk mengarahkan potensi, baik potensi dasar, maupun ajar yang sesuai dengan fitrahnya melalui proses intyelektual dan spiritual berlandaskan nilai Islam untuk mencapai kebahagian dinia dan akhirat. ${ }^{3}$ Lebih lanjut menurut Sri Minarti pendidikan Islam merupakan pendidikan yang secara khas memiliki ciri khas Islami, dimana kajiannya lebih memfokuskan diri kepada upaya pemberdayaan umat berdasarkan Alquran hadis. ${ }^{4}$ Jadi perbedaan dengan konsep pendidikan umum yang lebih menekankan upaya untuk memberdayakan manusia atas dasar ideologis, sosiologi, politis, ekonomi saja, tetapi dalam Islam individu didik dan diarahkan atas dasar keimananan yakni alquran dan hadist. ${ }^{5}$

Senada dengan yang disampaikan oleh Ramayulis dan Samsul Nizar bahwa pendidikan Islam merupakan suatu system yang memungkinkan peserta didik dapat ,mengarahkan kehidupannya sesuai dengan ideologi Islam. 'Maka, pendidikan Islam sebagaimana yang telah diuraiakan di atas baik secara kebahasaan maupun secara istilah merupakan proses bimbingan peserta didik baik jasmani dan rohaninya yang dilakukan secara sadar dan terencana untuk mengembangkan potensi peserta didik menuju terwujudnya pribadi yang cerdas, berkepribadian yang utama (akhlak mulia) dan terampil yang berguna bagi dirinya sendiri dan masyarakat yang berlandaskan kepada ajaran Islam guna tercapainya kebahagian di dunia dan akhirat.

Berdasarkan uraian dan penjelasan tentang konsep pembelajaran pendidikan agama islam di atas, secara bahasa dan secara istilah, baik menurut konsep pendidikan secara umum maupun menurut konsep Islam oleh para tokoh pendidikan di atas dapat ditarik suatu kesimpulan bahwa pembelajaran agama Islam merupakan suatu upaya dan usaha yang direncakanan dengan memberdayakan berbagai sumber daya (pendidik, sumber belajar, metode,media, lingkungan) untuk mengkondisikan dan merangsang Siswa untuk dapat belajar dengan baik, untuk mencapai tujuan pembelajaran sesuai dengan nilai-nilai ajaran Islam.

\section{Pendidikan Inqlusi}

Secara etimologi berasal dari bahasa inggris " inclusion " yang berarti terbuka. Banyak sekali interpretasi mengenai konsep pendidikan inklusi ini, Ada sebagian orang yang mengartikannya sebagai mainstreaming, ada juga yang

${ }^{3}$ Ibid, Moh. Salim haitami salim dan Syamsul Kurniawan. H.33

${ }^{4}$ Sri Minarti. 2013. Ilmu Pendidikan Islam. Jakarta. Amzah. 11

${ }^{5}$ Ibid, Sri Minarti. H.24

${ }^{6}$ Ramayulis dan Samsul Nizar. 2009. Filsafat Pendidikan Islam : Telaah System Pendidikan dan Pemikiran Para Tokohnya. Jakarta. Kalam mulia. H.88 
mengartikan sebagai fullinclusion yang berarti menghapus sekolah khusus. Namun demikian pengertian pendidikan inklusi pada umumnya adalah penyelenggaraan pendidikan bagi masyarakat yang mengalami hambatan baik fisik maupun psikis atau dalam arti lebih luas yaitu keterlibatan yang sebenarnya dari tiap anak dalam kurikulum, lingkungan dan interaksi yang ada di sekolah tanpa membeda-bedakan latar belakang. ${ }^{7}$

Secara terminologi Menurut Direktorat Jendral pendidikan luar biasa dengan mengambil pendapat para ahli, ada beberapa pengertian tentang pendidikan inklusi yang beragam, diantaranya yang dikemukakan oleh Stainback dan Stainback bahwa "sekolah inklusi adalah sekolah yang menampung semua di kelas yang sama". Sedangkan menurut Staub dan Peck bahwa pendidikan inklusi adalah menempatkan anak berkelainan tingkat ringan, sedang,dan berat secara penuh di kelas regular. Selanjutnya Sapon-Shevin mengemukakan bahwa pendidikan inklusi sebagai sistem layanan pendidikan yang mempersyaratkan agar semua anak berkelainan dilayani di sekolah-sekolah terdekat di sekolah reguler bersama-sama teman seusianya. ${ }^{8}$

Jadi pendidikan inqlusi adalah sistem layanan pendidikan yang mensyaratkan anak berkebutuhan khsusus belajar di sekolah- sekolah terdekat di kelas biasa bersama teman-eman seusisanya. Konsep pendidikan inqlusi merupakan konsep pendidikan yang mempresentasikan keseluruhan aspek yang berkaiatan dengan keterbukaan dalam menerima anak berkebutuhan khusus untuk memperoleh hak dasar mereka sebagai mereka sebagai warga negara.

Hak dasar anak ABK dalam mendapatkan layanan pendidikan bertujuan agar :

a. Berkembangnya kepercayaan pada diri anak, merasa bangga pada diri sendiri atas prestasi yang diperolehnya.

b. Anak dapat belajar secara mandiri, dengan mencoba memahami dan menerapkan pelajaran yang diperolehnya di sekolah ke dalam kehidupan sehari-hari.

c. Anak mampu berinteraksi secara aktif bersama teman-temannya, guru, sekolah dan masyarakat.

d. Anak dapat belajar untuk menerima adanya perbedaan, dan mampu beradaptasi dalam mengatasi perbedaan tersebut.

Sedangkan menurut Mohammad Takdir Ilahi, tujuan pendidikan inklusi ada dua macam, yakni:

a. Memberikan kesempatan yang seluas-luasnya kepada semua peserta didik yang memiliki kelainan fisik, emosional, mental, dan sosial atau

${ }^{7}$ Permendiknas, No. 41 Th. 2007, Tentang Standar Proses, hlm. 46

${ }^{8}$ Direktorat Pendidikan Luar Biasa, Mengenal Pendidikan Terpadu Ditjend. Pend. Dasardan Menengah Dep. Pend. Nasional, 2004, hlm. 8-10 
memilki potensi kecerdasan dan bakat istimewa untuk memperoleh pendidikan yang bermutu sesuai dengan kebutuhan dan kemampuannya.

b. Mewujudkan penyelenggaraan pendidikan yang menghargai keanekaragaman, dan tidak diskriminatif bagi semua peserta didik.

Pendidikan inqlusi sebagai suatu system pembelajaran khsusus memiliki karakter antara lain:

a. Kurikulum yang Fleksibel

Penyesuaian kurikulum dalam penerapan pendidikan inklusi tidak harus terlebih dahulu menekankan pada materi pembelajaran, tetapi yang paling penting adalah bagaimana memberikan perhatian penuh pada kebutuhan anak didik.Jika ingin memberikan materi pelajaran kepada anak berkebutuhan khusus, harus memperhatikan kurikulum apa yang tepat dan sesuai dengan kebutuhan mereka.

b. Pendekatan Pembelajaran yang Fleksibel

Aktivitas belajar mengajar, sistem pendidikan inklusi harus memberikan pendekatan yang tidak menyulitkan mereka untuk memahami materi pelajaran sesuai dengan tingkat kemampuan.

c. Sistem Evaluasi yang Fleksibel

Penilaian harus memperhatikan keseimbangan antara kebutuhan anak berkebutuhan khusus dengan anak normal pada umumnya.

d. Pembelajaran yang Ramah

Proses pembelajaran dalam konsep pendidikan inklusi harus mencerminkan pembelajaran yang ramah. Pembelajaran yang ramah bisa membuat anak termotivasi dan terdorong untuk terus mengembangkan potensi dan skill mereka sesuai dengan tingkat kemampuan yang dimiliki

e. Kurikulum Pendidikan Inqlusi

Kurikulum pendidikan inklusi menggunakan kurikulum sekolah reguler (kurikulum nasional) yang dimodifikasi (diimprovisasi) sesuai dengan tahap perkembangan anak berkebutuhan khusus, dengan memepertimbangkan karakteristik dan tingkat kecerdasannya.

Dalam pembelajaran inklusi, model kurikulum bagi anak berkebutuhan khusus dapat dikelompokkan menjadi empat, yakni, 1) duplikasi kurikulum, 2) modifikasi kurikulum, 3) subtitusi kurikulum 4) omisi kurikulum. 


\section{Anak Berkebutuhan Khusus}

Anak Berkebutuhan khusus merupakan individu yang memiliki kekurangan karena suatu hal khusus membutuhkan pelayanan pendidikan khusus, agar potensinya dapat berkembang secara optimal.). ${ }^{10}$ Dua hal penting yang menjadi dasar pengetahuan dan perlakuan yang harus diketahui tentang anak berkebutuhan khusus, yakni (1) perbedaan karakteristik dan (2) membutuhkan pendidikan khusus.

Anak berkebutuhan khusus memiliki Jenis- jenis antara lain

a.Anak Tunagrahita

Merupakan individu yang memiliki kecerdasan yang berada di bawah rata-rata yang disebut dengan retardasi mental. Dengan Klasifikasi Anak Tunagrahita berdasarkan tinggi rendahnya kecerdasan intelegensi yang diukur dengan menggunakan tes Stanford Binet dan skala Wescheler (WISC), tunagrahita digolongkan menjadi empat golongan: ${ }^{11}$

a) Kategori ringan, memiliki IQ 50-55 sampai 70 ..

b) Kategori Sedang (Imbesil) memiliki IQ 35-40 sampai 50-55

c) Kategori Berat (Severe) memiliki IQ 20-25 sampai 35-45.

d) Kategori Sangat Berat (Profound) memiliki IQ penderita dibawah 19.

b. Anak tuna netra

Anak Tunanetra yaitu anak yang memiliki hambatan dan kekurangan dalam penglihatan baik secara sebagian maupun secara keseluruhan. Kebutaan dapat digolongkan dalam dua golongan, yaitu buta total (Blind) dan low vision.Ciri-ciri anak yang menderita tunanetra adalah:

1) Ketajaman penglihatan kurang dari ketajaman yang dimiliki orang awas.

2) Terjadi kekeruhan pada lensa mata atau terdapat cairan tertentu.

3) Posisi mata sulit dikendalikan oleh syaraf otak.

4) Terjadi kerusakan susunan syaraf otak yang berhubungan dengan penglihatan. ${ }^{12}$

10 Dedy Kustawan, 2012. Pendidikan Inklusif dan Upaya Implementasinya.

Jakarta: Luxima Metro Media.h. 23

${ }^{11}$ Endang Rochyadi, Pengembangan Program PembelajaranIndividual Bagi Anak. Tunagrabita, (Jakarta: Departemen PendidikanNasional, 2005), hlm. 13

12 T. Sutjihati Somantri. 2007. Psikologi Anak Luar Biasa, (Bandung: PT. Refika Aditama. h. 65 . 
c. Anak Tunarungu

Anak Tunarungu merupakan anak yang memiliki hambatan dalam pendengaran, baik permanen maupun tidak permanen. Kekurangan dalam dalam pendengaran, cenderung juga memiliki hambatan juga dalam berbicara sehingga mereka sering disebut tunawicara. ${ }^{13}$. Karakteristik anak tunarungu yakni:

1) Kurang mampu mendengar.

2) Lambat perkembangan bahasa.

3) Menggunakan isyarat dalam berkomunikasi.

4) Tidak tanggap bila diajak bicara.

5) Ucapan kata tidak jelas.

6) Kualitas suara aneh.

7) Kadangkala memiringkan kepala dalam usaha mendengar.

8) Banyak perhatian terhadap getaran.

9) Keluar nanah dari dalam telinga.

10)Terdapat kelainan organis telinga. ${ }^{14}$

d. Anak tunadaksa

Anak Tunadaksa merupakan anak yang memiliki kekurangan dan hambatan serta gangguan gerakan yang disebabkan oleh kelainan neuromuskular atau struktur tulang yang bersifat bawaan, sakit, atau akibat kecelakaan. Individu tunadaksa di antaranya adalah celebral palsy, amputasi, polio, dan lumpuh, sehingga dapat dikatakan bahwa dengan dengan kekurangan secara fisik, baik kaki, tangan ataupun badan. ${ }^{15}$ dengan karakteristik 1) tubuh kaku/lemah/lumpuh, 2) sulit dalam bergerak atau beraktifitas 3) bagian tubuh yang tidak lengkap, 4) cacat pada alat gerak, 5) Jari tangan kaku dan tidak dapat menggenggam, 6) terhambat pada saat berdiri/berjalan/duduk, dan menunjukan sikap tubuh yang tidak normal, 7) hiperaktif/tidak dapat tenang. ${ }^{16}$

e. Anak Tunalaras

Tunalaras adalah individu yang mengalami hambatan dalam mengendalikan emosi dan kontrol sosial. Dengan karakteristik,

\footnotetext{
2013), h $2-3$

14 Geniofam. 2010. Mengasub dan Mensukseskan Anak Berkebutuban Khusus. Jogjakarta: Garailmu, h. 20-21

${ }_{15}$ B. Anggara, Kunci Mendidik dan Mengasuh Anak Disleksia, (Yogyakarta: Familia, t. th), h. 3

16 Geniofam. 2010. Mengasuh dan Mensukseskan Anak Berkebutuban Khusus. Jogjakarta: Garailmu, h. 22-23
}

13 Abu Ahmadi dan Widodo Supriyono, Psikologi Belajar Cet. 3,(Jakarta: Rineka Cipta, 
1) Suka membangkang,

2) Mudah tersulut emosi,

3) Suka melakukan tindakan agresif,

4) Suka bertindak melanggar norma sosial/norma susila/hukum.

\section{Hasil dan Pembahasan}

Pembelajaran merupakan suatu upaya dan usaha untuk merangsang dan memotivasi siswa untuk belajar dengan memaksimalkan semua sumber daya yang ada sehingga tujuan pembelajaran dapat tercapai. Tujuan pembelajaran merupakan suatu yang mutlak untuk dicapai, karena ia menjadi motor penggerak terjadinya aktivitas. Begitu pula halnya pembelajaran yang bertujuan untuk memberikan pengetahuan, keterampilan dan pembinaan sikap seorang peserta didik dalam menghayati dan melaksanakan ajaran agama yang dikenal dengan mata pelajaran pendidikan agama islam. pendidikan merupakan hak setiap manusia Indonesia yang dijamin oleh konstitusi. Dimana dalam pasal 31 ayat 1 tertera bahwa" setiap warga Negara berhak mendapatkan pendidikan. termasuk juga hlanya bagi anak atau peserta didik yang emmiliki kekurangan atau kelemahan dari sisi fisik dan psikis yang dikenal dengan Anak berkebtuhan khusus $(\mathrm{ABK})$.

Pembelajaran pendidikan Agma islam bagi anak berkebutuhan Khusus diajarkan dalam rangka untuk memberikan mereka bekal pengetahuan, keterampilan dan sikap(Akhlak) dalam rangka menghayati dan melaksanakan ajran agama yang dianutnya. Baik dalam melaksanakn iabadah mahdhoh maupun ibadah ghirog mahdhoh. Ibadah mahdhoh seperti Shalat, berpuasa, Berzakat, dan haji. Sedangkan ibadah ghoiruh mahdhoh seperti membaca alquran, bersedekah, memberikan infaq, menyatuni orang yang tidak mampu dan lain sebagainya.

Dalam menyusun dan melaksanakan pembelajaran bagi anak berkebutuhan khusus tentunya berbeda seperti anak yang normal. Baik normal secara fisik maupun secara fisik. Dimana Pola pembelajaran yang diimplementasikan di SDIT Al Aufa yakni pola pembelajaran guru dan media. Adapun pembelajaran yang dilakukan dengan tahapan-tahapan berikut:

\section{Menentukan Tujuan}

Pentingnya merumuskan dan menyusun tujuan dari suatu aktvitas tergambar dari penjelasan di atas, termasuk dalam menentukan tujuan yang hendak dicapai dalam suatu pembelajaran. Terutama pembelajaran Pendidikan Agama islam di Sekolah. Dalam hal ini tujuan pembelajaran dalam pembelajaran pendidikan agama islam di SDIT Al Aufa Kota Bengkulu, khsusnya tujuan pembelajaran bagi anak yang berkebutuhan Khusus sudah ada, walaupun belum tercatat dalam dalam draf dokumen. Akan tetapi, baru berupa tujuan yang dilaksanakan berdasarkan kesepakatan antara orang tua murid 
dengan pihak sekolah, yang di dalam perjanjian lisan tersebut pihak wali murid tidak menuntut lebih dan banyak kepada pihak sekolah. Akan tetapi walalupun tidak berdasarkan kesepakat tertulis dan tidak dituangakan secara langsung tujuan pembelajaran dalam sebuah dokumen pembelajaran, pihak sekolah berupaya maksimal untuk memberikan layanan kepada anak berkebutuhan khusus dengan memberikan layanan bimbingan dan arahan khusus satu kali satu minggu kepada anak ABK untuk memaksimalkan potensi dan bakat yang mereka miliki.

Tujuan pembelajaran bagi anak ABK sama halnya bagi anak normal yakni terakomodirnya ranah kognitif dan psikomotorik dan afektif. Pada aspek kognitif pembelajaran berlasngsung. Begitu pula pada aspek psikomotorik anak ABK juga diharapkan untuk dapat terampil mempergakan materi yang telah disampaikan oelh guru, seperti tata cara wudhu dan shalat. Selain kedua ranah di atas aspek yang tidak aklah penting juga, yakni aspek afektif/ perilaku. Dimana sebelum mereka diberikan pengajaran cara komunikasi atau bergaul anak ABK membuat anak normal menjadi tidak nyaman, dimana ketika mereka mau bermain mereka melakukan aktivitas seperti meludah dan memukul. Setelah mereka masuk di SDIT Al-aufa anak ABK pelan-pelan diberikan pengertian kalau mau berteman tidak boleh meludah dan memukul karena akan menyakiti teman-teman yang lain.

\section{Menentukan Materi Ajar}

Materi ajar merupakan seperangkat informasi, alat maupun teks yang tersusun secara sistematis yang memperlihatkan keseluruhan kompetensi yang harus dikuasai oleh siswa yang dilaksanakan dalam kegiatan pembelajaran. Materi ajar yang disusun hendaknya mempertimbnagkan kebutuhan siswa, sekolah dan daerah dimana dilaksanakannya kegiatan pendidikan. SDIT AL aufa dalam menyusun dan menyiadakan informasi dalam bentuk teks, gambar, symbol, foto dan lain sebagainya belum secara maksimal diwujudkan dalam bentuk penyedian sumber ajar yang bagi anak yang berkebutuhan khusus, hal ini belum terlihat dari bahan ajar yang disusun dan disediakan dalam bentuk draf yang utuh. Akan tetapi, dalam pelaksanaannya guru PAI telah mewujudkannya dengan menyederhanakan materi yang akan diberikan dan dikuasai oleh siswa. Dimana dalam penyempaian materi ajar siswa tidak dipaksakan untuk dapat menguasai seluruh materi ajar layaknya anan normal. Sebaliknya materi yang mereka dapatkan sesuai dengan kemampuan yang mereka miliki. Contohnya, ketika pembelajaran materi tentang rukun iman, bagi anak ABK tidak diwajibkan mereka untuk menguasai seluruh konsep tentang rukun dalam tauhid dalam islam. akan tetapi cukup menguasai tiga rukun saja. Sedangkan sisanya dapat mereka pelajari pada tingkat berikutnya.

Dalam implentasi materi ajar pendidikan agama islam di SDIT Al Aufa diajarkan seluruh dimensi, seperti pengajaran dengan materi tentang ketauhidan, akidah,ibadah, akhlak, muamalah, sejarah islam, pendidikan dan 
lain sebagianya. Pemberian materi ajar sebagaimana disebutkan merupakan bagian yang tidak bisa dipisahkan dari seorang muslim. Baik mereka yang dalam kondisi fisik dan fsikis lengkap, akan tetapi juga bagi mereka yang secara fisik dan fisik bermasalah memiliki hak yang sama untuk mendapatkan pengetahuan, wawasan, pendalaman tentang ajaran agama yang dianutnya yang pada akhirnya mereka akan menjalankan dan melaksanakan ajaran agama yang dianutnya tersebut.

\section{Menentukan Metode Dalam Pembelajaran PAI}

Metode dan merupakan salah satu bagian penting dari pendidikan. dimana metode merupakan cara dan jalan yang digunakan oleh pendidik dalam upaya menyampaikan materi ajar kepada peserta didik. Dalam pembelajaran PAI di Sdit al aufa digunakan metode pembelajaran sebgaiamana metode pembelajaran pada umumnya, baik ceramah, diskusi, demonstrasi dan lain sebagaianya. Belum ada metode khusus bagi anak ABK, akan tetapi dalam pembelajaran guru memberikan perhatian dan pengawasan khusus bagi ABK.

Dilihat dari sudut pandang pendidikan Islam metode memiliki kedudukan yang sangat penting dalam upaya pencapaian tujuan. Karena metode menjadi sarana pendidik dalam menyampaikan informasi, keterampilan dan sikap yang mesti dimiliki oleh peserta didik. Hal tersebut sangat beralasan, karena tanpa metode, maka materi yang akan disampaikan tidak akan berproses secara efektif dan efesien dalam usaha mencapai tujuan pendidikan. Begitu pula halnya apabila penggunaan metode tidak tepat akan menghambat proses belajar mengajar, yang pada akhirnya akan berimbas pada terkuras waktu dan tengaa secara percuma. Oleh karena pentingnya penerapan metode yang tepat, ada beberapa prinsip yang harus diperhatikan terutama bagi anak ABK sehingga mampu memberikan pengarahan dan pedoman dalam pelaksanaan metode pendidikan, dan bagi pendidik mampu menerapkan metode secara efektif dan efisien sesuai dengan kondisi dan kebutuhan. Adapun prinsip-prinsip tersebut yakni:

1. Mempermudah ${ }^{17}$

2. Berkesinambungan

3. Fleksibel dan dinamis

4. Prinsip memberikan suasana gembira

5. Prinsip memberikan layanan dan santunan dengan lemah lembut

6. Prinsip kebermaknaan

7. Prinsip Prasyarat

8. Prinsip Komunikasi Terbuka

9. Prinsip Pemberitahuan pengetahuan yang Baru

10.Prinsip memberikan model perilaku yang baik

11.Prinsip Pengalaman(praktik) secara aktif 


\section{Menentukan Media ajar PAI}

Media merupakan sarana atau perantara yang digunakan oleh guru dalam menyampaiakan meteri guna memudahkan pemahaman siswa yang dapat menimbukan efek. Media juga dipahami secara umum, sebagai segala sesuatu yang dapat memberikan pengetahuan, keterampilan, dan sikap kepada peserta didik, baik berwujud manusia, benda, atau kondisi. ${ }^{18}$

Begitu juga dalam pemanfaat media ajar guru PAI di SDIT Al Aufa menggunakan media atau sarana yang tersedia di sekolah, baik berupa papan tulis, media gambar, foto dan LCD proyektor, tujuan dari pengunaan media ajar dalam rangka memudahkan dan menciptakan suasana belajar yang kondusif, menyenangkan dan mampu memberikan informasi yang lebih jelas dan konkrit terhadap sesuatu yang tidak dapat disampaikan secara konvesional. lain: ${ }^{19}$

Ada beberapa manfaat penggunaan media dalam pembelajaran antara

a. Penyampaian pelajaran menjadi lebih baku.

b. Pembelajaran menjadi lebih menarik.

c. Pembelajaran menjadi lebih interaktif

d. Lama waktu pembelajaran menjadi lebih interaktif

e. Pembelajaran dapat diberikan kapan dan dan dimana saja

f. Peran guru dapat dikurangi, karena menyampaikan materi yang sama secara berulang-ulang.

Selain itu juga menurut Sudjana dan Rivai dalam Azhar Arsyad menyampaiakan manfaat media dalam proses belajar mengajar, yakni: ${ }^{20}$

a. Pembelajaran menjadi lebih menarik perhatian siswa sehingga dapat menumbuhkan motivasi belajar.

b. Bahan pembelajaran akan lebih jelas maknanya sehingga lebih difahami oleh siswa dan memungkinkan menguasai dan mencapai tujuan pembelajaran

c. Metode mengajar akan lebih bervariasi, tidak semata-mata komunikasi verbal melalui kata-kata.

d. Siswa dapat lebih banyak melakukan kegiatan belajar sebab tidak hanya mendengarkan uraian guru, tetapi juga aktivitas lain seperti mengamati, melakukan, mendemonstrasikan dan memerankan.

Besarnya peran dari media ajar yang disiapkan oleh guru dalam pembelajaran. Terutama bagi anak yang berkebutuhan khsusus, dengan adanya penggunaan media ajar berupa LCD proyektor guru dapat menyajikan materi secara lebih menarik dan komrehensif. Salah satu contohnya ketika guru menyajikan materi tentang sejarah. Maka guru tidak perlu bercerita berulang-

\footnotetext{
18 Azhar. Arsyad. 2013. Media Pembelajaran. Jakarta: Raja Grafindo Persada, h. 3

${ }^{20}$ Ibid., h. 28
} 
ulang secara verbal. Guru cukup menyajikan materi dengan memutar video suatu peristiwa atau kejadian. Seperti sejarah para sahabat, guru cukup memutar video bagaimana perjuangan para sahabat dalam memperjuangkan mensyiarkan islam ke seluruh dunia serta tantangan yang mereka hadapi daalm melawan kaum kafir.

\section{Evaluasi}

Evaluasi yang dilakukan oleh guru PAI di SDIT Al-aufa disusun dan disiapkan berlandasakan kepada kemampuan yang dimiliki oleh peserta didik. Dalam hal ini penyusunan butir soal dibuat secara sederhana sesuai dengan kemampuan anak ABK. Dimana dalam pelaksanaan jenis tes yang disediakan hanya sebatas tes pilihan ganda, dengan menggunakan bahasa yang mudah difahami oleh peserta $\mathrm{ABK}$.

Evaluasi merupakan salah satu bagian penting dalam pendidikan. hal ini dikarenakan tujuan akhir/keberhasilan dari suatu pembelajaran dapat diukur melalui evaluasi. Dimana evaluasi diartikan seperangkat tindakan atau proses untuk menentukan nilai sesuatu yang berkaitan dengan dunia pendidikan. ${ }^{21}$ Evauasi juga berarti menerapkan fenomena yang dianggap berarti di dalam hal yang sama berdasarkan sutu standar. ${ }^{22}$ Pentingnya evaluasi dalam pembelajaran sebagaiamana diungkapkan para ahli, yakni:

Evaluasi Dalam rangka mengimplementasikan prinsip keadilan, objektivitas., keikhlasan, maka evaluasi pendidikan bertujuan:

1. Untuk mengetahui dan mengumpulkan informasi tentang taraf perkembangan dan kemajuan yang didapatkan oleh peserta didik.

2. Untuk mengetahuai prestasi belajar siswa guna menetapkan keputusan, apakah pelajaran perlu diulang atau dilanjutkan.

3. Dapat mengetahui efektivitas proses belajar dan mengajar.

4. Untuk mengetahui ketersedian sarana dan prasaran serta efektivitas pemanfaatan media ajar.

5. Dapat mengetahui sejauhmana muatan kurikulum telah dipenuhi melalui proses belajar dan mengajar.

6. Dapat diketahui alokasi pembiayaan dalam berbagai kebutuhan sekolah. ${ }^{23}$

Tujuan evaluasi di atas berfungsi sebagai umpan balik terhadap kegiatan pembelajaran yang berguna untuk: $:^{24}$

1. Ishlah, yakni perbaikan terhadap semua komponen pendidikan.

\footnotetext{
${ }^{21}$ Yahya Qohar. 1972. Evaluasi Pendidikan. Jakarta: Bursa FIP IKIP.h.1

22 Departemen Pendidikan Dan Kebudayaan. 1983. Direktorat jenderal pendidikan tinggi. Penilaian Dalam Pendidikan.h.1

23 Ramayulis. 2015. Filsafat Pendidikan Islam : Analisis Filosofis Sistem Pendidikan Islam. Jakarta: PT Kalam Mulia. h.447

${ }^{24}$ Novan Ardi Wiyani dan Barnawi. 2012. Ilmu Pendidikan Islam. Jogjakarta. Ar-Ruzz Media.h.234
} 
2. Tazkiyah, yakni penyucian terhadap semua komponen pendidikan.

3. Tajdid, yakni memodernisasi semua kegiatan pendidikan.

4. Ad dhakil, yakni memasukan semua informasi dalam sebuah laporan berupa raport, ijazah, piagam dan lain sebagainya. ${ }^{25}$

Sementara menurut Sumadi Suryabrata, tujuan evaluasi dapat dikelompokan dalam tiga bagian:

1. Klasifikasi berdasarkan fungsinya yang meliputi kebutuhan, Psikologis, Didaktik/instruksional dan administrasi.

2. Klasifikasi berdasarkan keputusan pendidikan, yang dapat dijadikan dasar pengambilan keputusan individual, institusional, didaktik instruksional dan keputusan-keputusan penelitian.

3. Klasifikasi formatif dan sumatif. Dimana evaluasi formatif berguna sebagai umpan balik perbaikan proses belajar mengajar. Sedangkan evaluasi sumatif berfungsi mengukur keberhasilan seluruh program pendidikan pada akhir semester atau tahun.

Sedangkan menurut Muchtar Buchari, mengemukakan ada dua tujuan evaluasi: ${ }^{26}$

1. Untuk mengetahui kemajuan belajar peserta didik setelah menyadari pendidikan selama jangka waktu tertentu.

2. Untuk mengetahui tingkah efisien metode pendidikan yang dipergunakan dalam jangka waktu tertentu.

Selain pola atau bentuk pembelajaran yang diterapkan oleh guru pendidikan agama islam dalam kegiatan pembelajaran. Terdapat juga hambatanhambatan yang dihadapi oleh guru, sebagaimana informasi atau data penelitian yang didapatkan penulis pada waktu pengumpulan data. Adapun hambatan yang dihadapi oleh guru pendidikan islam ketika melaksanakan pembelajaran antara lain:

a. Lambatnya Merespon

Salah satu kelemahan dan kekurangan yang dimiliki oleh anak berkebutuhan khusus yang menjadi penghambat guru dalam memberikan pengajaran yakni, lambatnya anak berkebutuhan khusus dalam merespon atau menggapi materi yang disampaikan oleh guru. Sehingga dalam pembelajaran guru harus pelan-pelan dan hati, guru harus lebih sabar dan telaten dalam menyampaikan suatu materi ajar kepada siswa berkebutuhan khusus. Senada dengan pendapat dari anggara bahwa anak

${ }^{25}$ Sumadi Suryabrata. 1993. Proses Belajar Mengajar Di Perguruan Tinggi. Yogyakarta: Andi Offset.h. $34-48$

${ }_{26}$ Moh. Haitami Salim dan Erwin Mahrus. 2006. Filsafat pendidikan Islam.Pontianak: Pontianak Press 
berkebutuhan khusus memiliki karaterisk lamban dalam belajar, dengan kata lain membutuhkan waktu yang lama untuk memahami sesuatu, apalagi materi diajarkan bersifat abstrak susah untuk diterjemahkan ke ranah konkrit. ${ }^{27}$

b. Susah berkomunikasi dan bersosialisasi

Selain faktor lambat dalam merespon pelajaran, faktor komunikasi dan bersosialisasi juga menghambat terjadinya proses belajar mengajar yang efektif dan efisien dalam pembelajaran pendidikan agama islam bagi anak berkebutuhan khusus. Komunikasi yang dibangun oleh anak berkebutuhan khusus seringkali tidak jelas makna dan arti serta tujuan yang ingin disampaikan. Padahal komunikasi menjadi bagian penting yang tidak dapat dipisahkan dalam kaitan proses penyampaian pesan dari seseorang kepada orang lain. Dimana komunikasi merupakan suatu transaksi, proses simbolik yang menghendaki orang-orang mengatur lingkungannya dengan (1) membangun hubungan antarsesama manusia, (2) melalui pertukaran informasi, (3) untuk menguatkan sikap dan tingkah laku orang lain, serta (4) berusaha mengubah sikap dan tingkah laku itu. ${ }^{28}$

Senada pendapat dari Menurut D. Lawrence Kincaid, komunikasi adalah suatu proses dimana dua orang atau lebih membentuk atau melakukan pertukaran informasi dengan satu sama lainnya, yang pada gilirannya akan tiba pada saling pengertian yang mendalam.

Secara umum terdapat dua permasalahan dalam berbicara, kelainan yang terdapat pada alat wicara yang menyebabkan orang tersebut terganggu dalam memproduksi bahasa, dan gangguan berbahasa. Kemampuan berbicara merupakan kemampuan seseorang untuk menuturkan suatu bunyi atau huruf dan kelainan dalam bidang ini diistilahkan dengan gangguan berbicara (speech disorder), sedangkan kemampuan untuk menyampaikan ide dalam bentuk bahasa diistilahkan dengan kemampuan berbahasa dan mereka yang memiliki persoalandalam berbahasa dapat mengalami gangguan berbahasa (language disorder). ${ }^{29}$

Proses penyampaian informasi melalui komunikasi tidak hanya berfungsi sebagai instrument belaka, akan tetapi juga berfungsi secara sosial. Komunikasi sosial sangat penting untuk membangun konsep aktualisasi diri,untuk memperoleh kebahagian, terhindar dari tekanan dan ketegangan antara lain lewat komunikasi yang menghibur, dan memupuk

h.3

${ }^{27}$ B. Anggara, Kunci Mendidik dan Mengasuh Anak Disleksia, (Yogyakarta: Familia, t. th), h. $19-20$

${ }^{28}$ Hafied Cangara, Pengantar Ilmu Komunikasi (Jakarta: PT RajaGrafindo Persada, 2010), 29 Ilyas, M. Azizzullah, Diskursus Pemikiran Al-Jabiz. Mengenai Gangguan Berbahasa. Jurnal Arabiyatuna, Vol.2, No.2 (2018). 
hubungan dengan orang lain. Dalam proses pembelajaran dengan komunikasi peserta didik bisa saling bekerja sama dan berdiskusi berkaitan dengan materi yang sedang dipelajari. Komunikasi bagi peserta didik dapat juga menambah pengetahuan untuk mencari solusi yang sedang mereka hadapi. Menurut Deddy Mulyana komunikasi merupakan mekanisme untuk mensosialisasikan norma-norma masyarakat, baik secara horizontal dari suatu masyarakat kepada masyarakat laninya, ataupun secara vertikal dari suatu generasi kepada generasi berikutnya. ${ }^{30}$

Selain komunikasi, kemampuan dalam bersosialisasi juga menjadi hambatan dalam memberikan pengajaran bagi anak berkebutuhan khusus. Dimana mereka mengalami kesulitan dalam beradabtasi dengan lingkungan dimana mereka berada. Anak berkebutuhan khusus tidak mampu mengurusi diri sendiri dan memikul tanggungjawab yang diberikan dan dibebankan oleh lingkungan. Oleh karena itu, dalam pergaulannya mereka harus selalu diawasi dan dikontrol setiap waktu.

c. Anak berkebutuhan khusus hiperaktif (susah diatur)

Anak berkebutuhan khusus dalam pergaulan dan interaksi dengan lingkungan, terutama ketika belajar mereka cenderung susah diatur, dan bersikap sesuai dengan kehendaknya sendiri. Ketika proses belajar mengajar mereka seringkali keluar dan masuk ruangan. Apabila mereka dikerasi, maka mereka akan marah ataupun akan teriak. Oleh karena itu, harus bisa memahami dan mengarahkan anak berkebutuhan khusus agar kondisinya menjadi senang dan tidak bosan. Salah satu caranya dengan memutar video pada LCD proyektor yang sudah disiapkan. hal ini dilakukan untuk menghindari kebosanan dalam belajar, tentunya tidak hanya untuk ABK saja, akan tetapi juga bagi anak normal. Sebagaimana pendapat dari Sudjana dan Rivai dalam Azhar Arsyad menyampaikan manfaat media dalam proses belajar mengajar, yakni: ${ }^{31}$ a) Pembelajaran menjadi lebih menarik perhatian siswa sehingga dapat menumbuhkan motivasi belajar, b) Bahan pembelajaran akan lebih jelas maknanya sehingga lebih difahami oleh siswa dan memungkinkan menguasai dan mencapai tujuan pembelajaran. Oleh karena itu, pemanfaatan media guna mengurangi aktivitas anak $A B K$ bersifat hiperaktif menjadi sangat membantu.

30 Deddy Mulyana, 2005. Ilmu Komunikasi, Suatu Pengantar. Bandung: PT. Remaja Rosdakarya, h.7

${ }^{31}$ Azhar. Arsyad. 2013. Media Pembelajaran. Jakarta: Raja Grafindo Persada, h. 28 


\section{Penutup}

Pembelajaran merupakan upaya dan usaha yang dirancang dan dilaksanakan oleh seorang pendidik untuk menciptakan dan mengkondisikan agar peserta didik dapat belajar dengan baik sesuai dengan tujuan pembelajaran. Hal tersebut menjadi sangat penting terutama bagi peserta didik yang dalam kondisi memiliki kekurangan dan kelemahan, baik secara fisik dan psikis yang dikenal dengan Anak berkebutuhan Khusus(ABK). Pola pembelajaran yang diterapkan Di SDIT Al Aufa Kota Bengkulu yakni, pola pembelajaran Guru dan media. Dimana pada pola pembelajaran ini tahapan pembelajaran diawali dari 1) Menentukan tujuan yang lebih menekankan pada aspek afektif dan psikomotorik. 2) Menentukan materi/ bahan ajar sesuai dengan kemampuan anak ABK yang lebih disederhanakan. 3) Menetapkan metode pembelajaran. 4) menentukan media atau sarana belajar yang dapat stimulus anak untuk semangat belajar dan 5) dengan menyusun alat evalusi yang sederhana sehingga dapat dengan mudah difahami oleh ABK.

Aktivitas pembelajaran pendidikan agama islam bagi anak ABK tidak terlepas dari berbagai kendala dan hambatan antara lain, 1) ABK yang memiliki karakter hiperaktif, lambat merespon stimulus, susah bersosialisasi dan berkomunikasi. Oleh karena kompleksnya pembelajaran pendidikan agama islam terutama bagi Anak ABK, maka hendaknya desain pembelajaran yang disusun dengan memperhatikan berbagai faktor dan kebutuhan peserta didik.

\section{Daftar Pustaka}

Abu Ahmadi dan Widodo Supriyono,2013. Psikologi Belajar Cet. 3,Jakarta: Rineka Cipta.

Azhar. Arsyad. 2013. Media Pembelajaran. Jakarta: raja Grafindo Persada.

B. Anggara, Kunci Mendidik dan Mengasuh Anak Disleksia, (Yogyakarta: Familia, t. th>)

Borry moris dalam Rusman. Tt. Pendekatan Dan Model Pembelajaran.

Deddy Mulyana. 2005. Ilmu Komunikasi, Suatu Pengantar (Bandung: PT. Remaja Rosdakarya.

Dedy Kustawan, 2012. Pendidikan Inklusif dan Upaya Implementasinya. Jakarta: Luxima Metro Media

Departemen Pendidikan Dan Kebudayaan. 1983. Direktorat jenderal pendidikan tinggi. Penilaian Dalam Pendidikan.

Direktorat Pendidikan Luar Biasa. 2004. Mengenal Pendidikan Terpadu Ditjend. Pend. Dasardan Menengah Dep. Pend. Nasional.

Endang Rochyadi. 2005. Pengembangan Program PembelajaranIndividual Bagi Anak Tunagrahita, Jakarta: Departemen PendidikanNasional. 
Geniofam. 2010. Mengasub dan Mensukseskan Anak Berkebutuban Khusus. Jogjakarta: Garailmu.

Hafied Cangara. 2010. Pengantar Ilmu Komunikasi (Jakarta: PT RajaGrafindo Persada.

Ilyas, M. Azizzullah, Diskursus Pemikiran Al-Jahiæ, Mengenai Gangguan Berbahasa. Jurnal Arabiyatuna, Vol.2, No.2 (2018)

Moh. Haitami Salim dan Erwin Mahrus. 2006. Filsafat pendidikan Islam.Pontianak: Pontianak Press

Novan Ardi Wiyani dan Barnawi. 2012. Ilmu Pendidikan Islam. Jogjakarta. ArRuzz Media.

Permendiknas, No. 41 Th. 2007, Tentang Standar Proses,

Ramayulis dan Samsul Nizar. 2009. Filsafat Pendidikan Islam : Telaah System Pendidikan dan Pemikiran Para Tokobnya. Jakarta. Kalam mulia.

Ramayulis. 2015. Filsafat Pendidikan Islam : Analisis Filosofis Sistem Pendidikan Islam. Jakarta: PT Kalam Mulia.

Sri Minarti. 2013. Ilmu Pendidikan Islam. Jakarta. Amzah.

Sumadi Suryabrata. 1993. Proses Belajar Mengajar Di Perguruan Tinggi. Yogyakarta: Andi Offset.

T. Sutjihati Somantri. 2007. Psikologi Anak Luar Biasa, (Bandung: PT. Refika Aditama.

Yahya Qohar. 1972. Evaluasi Pendidikan. Jakarta: Bursa FIP IKIP. 